\title{
PENGEMBANGAN MODUL CETAK PEMBELAJARAN REMEDIAL UNTUK PENINGKATAN KETUNTASAN BELAJAR MATA PELAJARAN BAHASA INDONESIA SMP KELAS VIII
}

\author{
Supkarwati $^{1}$, Nurdin Ibrahim ${ }^{2}$ Priyono $^{3}$
}

\section{Info Artikel}

Sejarah Artikel:

Diterima: 31 Januari 2019

Direvisi: 3 Maret 2019

Dipublikasikan: April 2019

e-ISSN: 2620-3081

p-ISSN: 1411-2744

DOI: https://doi.org/10. 21009/itp.v21i1.11246

\begin{abstract}
The purpose of this study is to produce of a print module remedial learning of Indonesian Language for class VIII Junior High School. The methodology used is the method research and development. This research using model of Derek Rowntree which consists of three stages: namely the planning states, the preparing for writing stage, and phase writing and re-writing. The results showed earming average score of material and language expert 3,8 means the product is concidere very good. The results showed earming average score of design expert 3,7 means the product is concidere very good too. Later the one to one test, the result showed earming average score 3.7 means the product is concidere very good. The results showed earming average score post test of the small group trials 82. The means the product is able to improve learing outcomes. Later the field trip test, the result showed earming average score post test of the field trip test 81 . The means the product is able to improve learing outcomes too. In conclusion the print module remedial learning of Indonesian Language for class VIII Junior High School can be said to be good for remedial learning.
\end{abstract}

Keywords: research development, rowntree models, print module, remedial learning

Abstrak: : Penelitian ini bertujuan untuk menghasilkan modul pembelajaran remedial mata pelajaran Bahasa Indonesia kelas III SMP. Metodologi yang digunakan adalah metologi penelitian pengembangan. Model yang digunakan adalah model Derek Rowntree dengan 3 tahapan, yaitu tahap perencanaan, tahap persiapan penulisan, serta tahap penulisan dan penyuntingan. Hasil penelitian menunjukkan nilai rata-rata dari ahli materi dan bahasa sebesar 3,8. Hal itu menunjukkan bahwa produk yang dihasilkan sangat bagus. Hasil penelitian oleh ahli desain menunjukkan rata-rata 3,7. Artinya, produk ini sangat bagus. Berdasarkan uji satu-satu, hasil rata-rata sebesar 3,7. Artinya, modul ini hasilnya sangat bagus. Dari uji kelompok kecil, nilai rata-rata post test sebesar 82. Ini berarti modul mampu meningkatkan prestasi hasil belajar remedial dengan. Dari ujicoba lapangan, nilai ratarata post test sebesar 81. Ini berarti, modul mampu meningkatkan prestasi hasil belajar remedial. Dapat disimpulan bahwa modul cetak pembelajaran remedial bahasa Indonesia untuk siswa kelas VIII SMP dapat dikatakan bagus untuk pembelajaran remedial.

Kata kunci: penelitian pengembangan, model Rowntree, modul cetak, pembelajaran remedial

(C) 2019 PPS Universitas Negeri Jakarta

\footnotetext{
${ }^{1}$ SMP Negeri179 Jakarta, Jalan Kalisari Pasar Rebo Jakarta Timur 13790, 0218711073 , supkarwati179@gmail.com

${ }^{2}$ Dosen Program Studi Teknologi Pendidikan Pascasajana UNJ, Jakarta, 0812999343

${ }^{3}$ Dosen Program Studi Teknologi Pendidikan Pascasarjana UNJ, Jakarta, 081338317400, mrpriyonohw@gmail.com
} 


\section{PENDAHULUAN}

Peserta didik memiliki kecerdasan dan daya tangkap yang berbeda-beda. Undang-Undang Pendidikan Nasional menuntut diberikannya pelayanan pendidikan kepada peserta didik sesuai dengan kemampuannya. Peserta didik harus diberikan kesempatan untuk mencapai ketuntasan belajarnya. Guru perlu menyediakan sejumlah alternatif strategi pembelajaran bagi siswa yang mengalami ke-sulitan belajar (Zein, 2014: 15). Berdasarkan hasil belajar itulah, guru melakukan analisis peserta didik yang perlu diberikan pembelajaran remedial dan menganalisis Kompetemsi Dasar (KD) dan indikator yang perlu diberkan pembelajaran remedialnya.

Remedial merupakan program pembe-lajaran yang diperuntukkan bagi peserta didik yang belum mencapai Kriteria Ketuntasan Minimal (KKM) dalam suatu KD tertentu (Gantini, 2017: 51) dan tujuannya adalah untuk membantu dan menyembuhkan peserta yang mengalami kesulitan belajar melalui perlakuan pengajaran (Arifin, 2017: 304). Pembelajaran dilakukan segera setelah diketahui kalau peserta didik belum mencapai KKM. Pembelajaran remedial dilakukan untuk memenuhi hak peserta didik. Dalam pem-belajaran remedial, guru membantu peserta didik untuk memahami kesulitan belajar yang dihadapinya secara mandiri, mengatasi kesulitan dengan memperbaiki sendiri cara belajar dan sikap belajarnya sehingga dia dapat mencapai hasil belajarnya secara optimal.

Hasil observasi dan wawancara yang di-lakukan peneliti kepada guru mata pelajaran Bahasa Indonesia dan peserta didik di sebuah SMP di wilayah Jakarta Timur, diperoleh data sebagai berikut. Guru sudah melakukan analisis hasil penilaian harian dan menyimpul-kan peserta didik tuntas atau tidak tuntas dalam pembelajaran. Guru sudah memberikan kegiatan remedial kepada peserta didik yang belum tuntas. Peserta didik diminta belajar sendiri di rumah, lalu pada pertemuan selanjutnya diberikan soal yang sama. Bentuk kegiatan remedial lainnya, peserta didik hanya diminta mengerjakan soal yang sama secara mandiri di rumah. Guru belum memiliki rencana khusus untuk kegiatan remedial. Biasanya, materi pun tidak disiapkan secara khusus. Guru menggunakan cara yang praktis. Yang penting bagi guru, nilai peserta didik berubah tanpa perlu memberikan perlakuan pembelajaran khusus.

Guru mengalami kesulitan jika remedial dilaksanakan di luar jam pelajaran. Seringkali, waktu yang ditentukan untuk remedial akan berbenturan dengan waktu kegiatan guru yang harus mengajar di kelas yang lain atau juga dengan jadwal peserta didik dengan kegiatan mata pelajaran lain maupun kegiatan ekstrakurikuler.

Remedial seperti itu membuat peserta bingung mencari bahan materinya sehingga mereka pun tidak mampu menguasai materi secara optimal. Remedial yang hanya mengulang kembali tes yang sama tanpa pembelajaran ulang membuat mereka semakin bingung. Terlebih jika pelaksanaannya tetap di dalam kelas bersamaan dengan kegiatan pembelajaran KD lain.

Pelaksanaan kegiatan remedial kurang optimal karena ditemukan sejumlah masalah. Permasalahan di atas dapat dikaji dengan pendekatan Teknologi Pendidikan. Kegiatan pembelajaran remedial merupakan sebuah sistem. Komponen-komponen sistem pem-belajaran dianalisis satu persatu untuk dilihat di sisi mana terjadi persoalan agar dapat dicarikan solusi terbaik mengatasi persoalannya. 
Komponen pembelajaran remedial mulai dari peserta didik, tujuan, bahan pembelajaran, strategi pembelajaran, media pembelajaran, dan alat evaluasi harus dapat dievaluasi sedemikian rupa. Berdasarkan hasil evaluasi, lalu dicarikan solusi yang tepat sehingga mampu menjadikan pembelajaran remedial sangat efektif dan efisien mencapai tujuan yang diharapkan.

Kegiatan remedial dapat meningkatkan kemampuan peserta didik mengejar keter-tinggalan kemampuannya. Jangid (2016) ber-dasarkan hasil penelitianya menjelaskan kalau peserta didik yang lambat belajar biasanya memiliki kemampuan yang rendah dalam: mengintegrasi informasi baru dengan in-formasi yang sudah dimilikinya, proses menyampaikan informasi, proses menafsirkan infomasi, kemampuan mendiagnosis masalah, berpikir secara deduktif maupun induktif, maupun kemampuan memprediksi pemecahan masalah. Kegiatan pembelajaran remedial mampu meningkatkan kemampuan belajar peserta didik.

Banyak cara yang dapat dilaksanakan dalam pembelajaran remedial. Haryati (2010: 111-112) menguraikan cara pemberian pem-belajaran remedial dapat berupa: (1) pemberi-an bimbingan secara khusus dan perseorangan bagi peserta didik yang mengalami kesulitan dalam pencapaian indikator dari suatu kom-petensi; dan (2) pemberian tugas-tugas atau perlakuan khusus sebagai bentuk penyederhanaan dari sistem pembelajaran reguler; penyederhanaan isi materi ajar untuk setiap KD; penyederhanaan penyajian materi atau bahan ajar; dan penyederhanaan soal penilaian yang diberikan.

Chau (2017) melakukan penelitian pem-belajaran remedial dengan melihat pengaruh pembelajaran menganalisis video 3D dan pen-dekatan respon interaktif pada pengajaran remedial sains Hasilnya menjelaskan bahwa model pembelajaran tersebut dapat me-ningkatkan hasil pembelajaran.

Peserta didik membutuhkan sarana belajar lain dalam bentuk cetak yang dapat dipelajari secara mandiri berulang-ulang di rumah. Sarana belajar itu diharapkan berisi uraian tujuan, materi berupa model teks yang lengkap untuk diidentifikasi cirinya, dipahami isinya, dianalisis struktur dan unsur kebahasaannya lengkap dengan penjelasannya. Mereka juga butuh bahan belajar yang di dalamnya ada bahan-bahan evaluasi untuk diujicobakan secara mandiri.

Sarana belajar yang memungkinkan di-lakukannya hal tersebut tentu saja berupa modul. Modul dapat menjadi sarana pem-belajaran yang dapat disediakan guru untuk dimanfaatkan dalam pembelajaran remedial.

Bahan pembelajaran yang digunakan dalam pendekatan pembelajaran mandiri disebut bahan pembelajaran mandiri seperti yang digunakan dalam pembelajaran jarak jauh. Bahan pembelajaran tersebut biasa disebut modul dengan penataan isi pem-belajaran ke dalam suatu format khusus sehingga dapat dipelajari peserta didik secara mandiri tanpa bergantung pada kehadiran pengajar secara terus menerus. Modul tersebut mengandung isi pembelajaran yang lengkap dan mampu menjelaskan sendiri (Suparman, 2012:44).

Modul yang dikembangkan harus dapat membuat pembelajaran remedial menjadi efektif dan efisien mencapai hasil belajar sehingga memperoleh nilai tuntas. Pembelajaran remedial adalah suatu proses untuk memahami dan meneliti dengan cermat mengenai berbagai kesulitan peserta didik (Arifin, 
2017:304). Modul sengaja dipilih penulis untuk mengatasi masalah dalam pembelajaran remedial. Pembelajaran remedial merupakan hak yang harus diperoleh peserta didik ketika mereka tidak menguasai kompetensi-kompetensi tertentu setelah belajar klasikal. Artinya, mereka butuh pembelajaran individual tentang KD yang tidak terkuasainya sampai mencapai tingkat ketuntasan.

Sesunguhnya tujuan remedial adalah untuk membantu dan menyembuhkan peserta didik yang mengalami kesulitan belajar melalui perlakuan pengajaran (Arifin, 2017: 304). Haknya bukan sekadar angka nilai yang berubah melainkan sebuah proses pembelajaran yang mengantarkan mereka jadi kompeten atau mampu.

Kamar, dkk (2016) menghasilkan produk ASFORDIASI BEKOM yaitu asesmen for-matif yang terintegrasi dengan bahan remedial berbasis komputer. Produk ini mampu meng-identifikasi pemahaman konsep peserta didik bahkan materi pembelajaran remedial untuk butir soal yang tidak terjawab benar langsung terintegrasi. Namun, produk ini masih bersifat offline sehingga peserta didik tidak dapat melakukannya di luar jam pelajaran. Produk ini belum dapat dipilih karena peserta didik masih menghendaki produk cetak. Mereka terkendala oleh sarana komputer dan waktu pemanfaatan.

Modul cetak yang akan menjadi pilihan. Walaupun cetak, bahan belajar tetap men-datangkan pengaruh dalam meningkatkan hasil belajar sebagaimana hasil penelitian di Nilasari, dkk (2016). Penelitinya menguji kemampuan pemanfaatan modul pembelajaran kontekstual terhadap peningkatan hasil belajar. Berdasarkan hasil penelitian, modul pem-belajaran kontekstual yang digunakan pada siswa SD dapat meningkatkan kemampuan hasil belajar siswa secara signifikan. Hal ini menunjukkan bahwa modul dapat dimanfaat-kan untuk meningkatkan hasil belajar.

Penelitian yang hampir sama pernah dilakukan Seputra, dkk (2017). Penelitian dilaksanakan untuk melihat ada tidaknya hubungan pemanfaatan modul pembelajaran terhadap hasil belajar pembuatan pola kemeja pria kelas XI SMK. Hasil penelitian menunjukkan bahwa terdapat hubungan positif dan signifikan antara pemanfaatan modul pembelajaran. Hasil belajar peserta didik pada pembuatan pola kemeja pria di SMK yang menggunakan modul jauh lebih tinggi. Hasil penelitian ini membuktikan kalau modul dapat dipakai untuk meningkatkan hasil belajar peserta didik.

Modul cetak pernah dikembangkan untuk Mata Pelajaran Teknik Komputer Jaringan dalam sebuah penelitian pengembangan (Muldiyana: 2018). Hasilnya menunjukkan kalau Model Rowntre mampu digunakan untuk mengembangkan modul yang kualitasnya baik.

Berdasarkan hasil penelitian-peneltian di atas, dikembangkan modul pembelajaran remedial Bahasa Indonesia. Modul yang di-kembangkan digunakan untuk mengatasi masalah pelaksanaan pembelajaran remedial di kelas VIII yang akan digunakan secara mandiri. Modul merupakan satuan pem-belajaran terkecil secara perseorangan (Prastowo, 2011:105) yang dapat digunakan secara mandiri (Sitepu, 2006:107). Modul merupakan bahan pembelajaran yang disusun dengan tujuan agar peserta didik dapat belajar tanpa guru (Ibrahim: 2010:1). Peserta dapat melakukan pembelajaran remedial secara belajar mandiri merupakan belajar aktif yang motifnya untuk mengatasi suatu masalah dan dilakukan dengan bekal kompetensi yang telah dimiliki (Mudjiman, 2011:1). 
Penelitian pengembangan dilakukan sebagai sebuah studi sistematis tentang desain dan evalusi program, proses dan produk yang harus memenuhi kriteria konsistensi internal dan efektivitas (Richey, 2007:1). Artinya, modul yang dikembangkan dihasilkan dari hasil evaluasi terhadap lapangan.

Sebagai sebuah sistem, modul pem-belajaran dirancang melalui proses dengan langkah yang bertahap agar produk yang di-hasilkan bagus kualitasnya dan berdaya guna untuk meningkatkan kompetensi pengetahuan dan keterampilan peserta didik pada Kom-petensi Dasar yang belum tuntas.

Penelitian ini difokuskan pada pengem-bangan modul cetak pembelajaran remedial mata pelajaran Bahasa Indonesia SMP kelas VIII semester ganjil.

Masalah dalam penelitian dirumuskan sebagai berikut: (1) Bagaimanakah prosedur pengembangan modul cetak pembelajaran remedial mata pelajaran Bahasa Indonesia SMP Kelas VIII semester ganjil? (2) Bagai-manakah kualitas modul cetak pembelajaran remedial yang dikembangkan dari segi media dan materi? (3) Apakah modul cetak yang dikembangkan efektif untuk mencapai ketuntasan belajar Bahasa Indonesia pada peserta didik kelas VIII?

Penelitian diharapkan dapat memenuhi kebutuhan para peserta didik untuk semakin mudah dalam belajar secara mandiri sehingga semakin kompeten pada ranah pengetahuan dan ranah keterampilan dalam pembelajaran remedial Bahasa Indonesia kelas VIII. Hasil penelitian dapat dijadikan sebagai model dalam mengembangkan media pembelajaran di sekolah. Hasilnya dapat dijadikan bahan masukan kepada para guru untuk mampu mendesain dan mengembangkan sarana pem-belajaran yang efektif dan efisien. Penelitian dapat menjadi bahan penelitian lanjutan untuk penerapan atau penyebaran hasil pengembang-an produk di bidang yang sama ataupun pengembangan media pembelajaran di bidang lainnya.

\section{METODE PENELITIAN}

Kegiatan penelitian pengembangan ini bertujuan untuk menghasilkan sebuah produk yang berupa modul pembelajaran remedial mata pelajaran Bahasa Indonesia SMP kelas VIII. Modul dikemas dalam bentuk cetak yang dapat digunakan untuk pembelajaran remedial secara mandiri.

Pendekatan yang dilakukan dalam pe-nelitian ini adalah pendekatan pengembangan pembelajaran berbasis produk dan mengguna-kan model pengembangan Rowntree. Pe-nelitian ini diawali dari mengkaji per-masalahan dengan melakukan analisis kebutuhan pembelajaran di sekolah untuk menentukan perlu atau tidaknya paket modul yang dapat membantu proses pembelajaran. Model pembelajaran berbasis produk juga melibatkan ahli yang sesuai dengan klasifikasi akademiknya dan di luar lembaga yang me-miliki tenaga akademik tetap.

Langkah-langkah pengembangan paket modul cetak pembelajaran remedial Bahasa Indonesia Kelas VIII adalah sebagai berikut:

\section{Penelitian Pendahuluan}

Pada tahap ini dilakukan tahap analisis kebutuhan. Peneliti melakukan observasi ke sekolah untuk melihat permasalahan, keadaan, serta karakteristik siswa. Selain observasi, peneliti juga menyebarkan 
kuesioner wawancara pada siswa dan guru mata pelajaran bahasa Indonesia. Pertanyaan yang diajukan lebih khusus mengenai kegiatan remedial, menyangkut minat belajar, sarana yang digunakan, kendala, dan hasil kegiatan.

\section{Perencanaan Pengembangan Produk}

Tahap selanjutnya yang dilakukan adalah mendesain modul pembelajaran dengan meng-gunakan model Rowntree. Model ini melalui 3 tahapan, yaitu planning, reparing for writing, dan writing and rewriting (Rowntree, 1994:5).

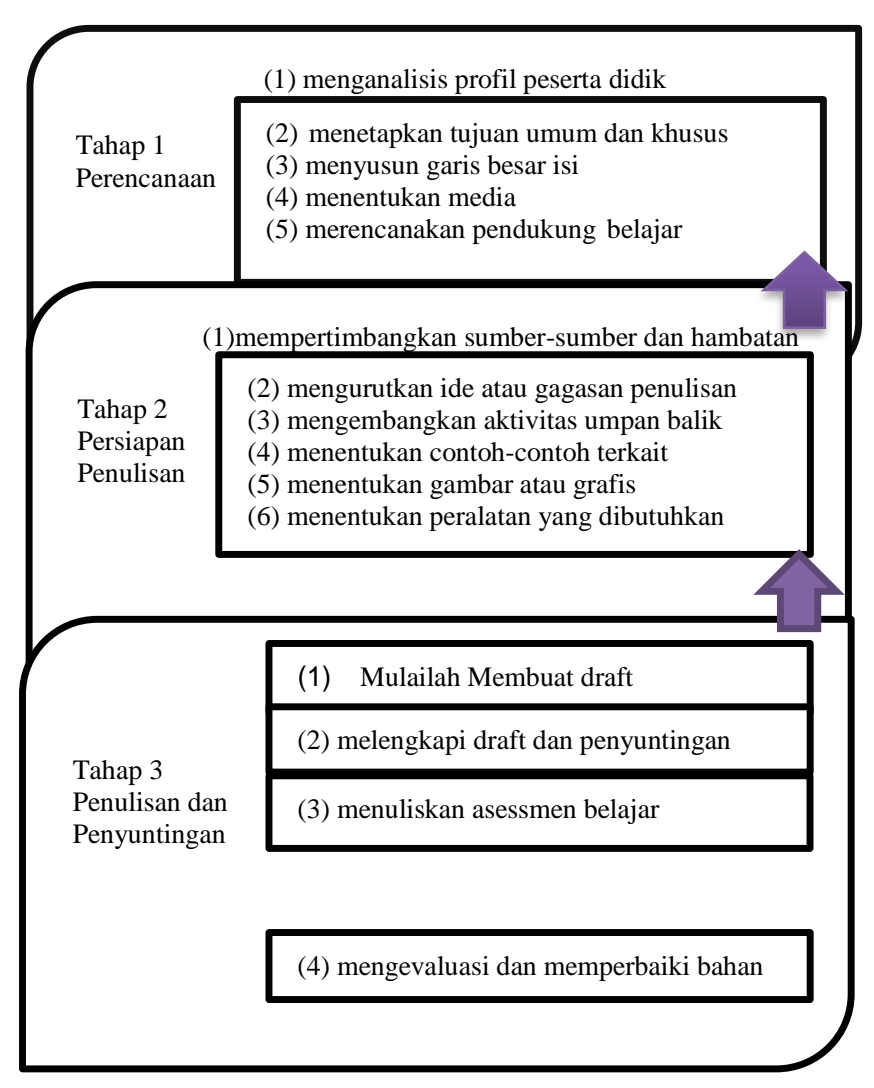

Gambar 1 Langkah Pengembangan Modul

\section{Validasi, Evaluasi, dan Revisi Modul}

Paket modul pembelajaran yang telah dikembangkan ini divalidasi dan dievaluasi dengan melibatkan beberapa responden, yaitu: (1) ahli media: untuk memberikan penilaian dan masukan pada produk yang dikembang-kan; (2) ahli materi pendidikan bahasa Indonsia. Ahli materi akan memberikan penilaian mengenai ketepatan materi yang disajikan pada produk yang dikembangkan; dan (3) pengguna/siswa.: untuk menilai modul yang dikembangkan sudah baik dan sesuai dengan kebutuhan siswa.

Evaluasi yang digunakan dalam pengembangan ini adalah evaluasi formatif. Evaluasi formatif adalah evaluasi yang dilakukan selama perencanaan atau produksi bahan instruksional untuk menentukan apa kekurangan produk. Jika ada, revisi harus dilakukan untuk membuat lebih modul lebih baik dan berguna. Evaluasi formatif digunakan karena evaluasi ini dilakukan ketika paket modul 
diujicobakan kepada sasaran pengguna paket modul dengan tujuan agar tahap-tahap pengembangan yang telah dilakukan serta isi materi dalam penyusunan paket modul ini dapat dievaluasi dan diperbaiki.

Untuk mengevaluasi paket modul yang telah dikembangkan digunakan instrumen yang buat untuk menilai paket modul dari aspek pembelajaran, desain pesan dan media. Instrumen dibuat berdasarkan validitas konstruk, yaitu menjabarkan kerangka dalam suatu konsep pengembangan paket modul.

Tahapan uji coba paket modul pembelajaran remedial adalah sebagai berikut.

Pada tahap expert rieview, produk yang telah didesain dicermati, dinilai, dan dievaluasi oleh pakar. Saran-saran para pakar digunakan untuk merevisi paket modul pembalajaran yang dikembangkan. Tanggapan dan saran para pakar (valiator) tentang desain yang telah dibuat ditulis pada lembar validasi sehingga bahan merevisi dan menyatakan apakah desain ini telah valid atau tidak. Pada tahapan ini, ahli media dan ahli materi memberikan penilaian dengan menggunakan format yang telah dibuat. Skala penilaian yang digunakan pada masing-masing instrumen untuk menguji modul pembelajaran terdiri dari empat kategori yang telah diatur oleh peneliti berdasarkan pada kriteria interpretasi skor untuk skala Likert.

Modul diujicobakan kepada siswa. Pada tahapan face to face dilakukan kepada dua atau tiga orang siswa yang dipilih berdasarkan nilainya yang bahasa Indonesia semester 1-nya rendah. Tahapan uji coba ini juga biasa disebut one-to-one evaluation. Hasil dari tahapan ini digunakan untuk merevisi modul sebelum uji coba lapangan.

Hasil revisi dari tahap kedua diujicobakan ke subjek penelitian dalam hal ni sebagai uji lapangan atau field test. Pada tahap ini, paket modul diujikan kepada peserta didik dalam jumlah besar. Peserta diminta untuk mengerjakan pretest kemudian modul dibagikan untuk kemudian digunakan. Karena modul yang dkembangkan merupakan bahan ajar mandiri, maka siswa diberi waktu selama 5 hari untuk menggunakan paket pembelajaran tersebut. Setelah itu, siswa diminta untuk mengisi post-test untuk menguji tingkat ketercapaian dalam materi bahasa Indonesia pada saat post-test.

\section{HASIL PENELITIAN DAN PEMBAHASAN}

Penelitian pengembangan produk telah dilakukan dengan serangkaian kegiatan yang sistematis. Kegiatan studi pendahuluan telah dilaksanakan melalui kegiatan observasi dan wawancara mengenai kegiatan remedial Bahasa Indonesia. Kegiatan dilaksanakan di bulan Januari 2018. Tujuan observasi adalah untuk melihat permasalahan pembelajaran terutama yang berkait dengan hasil belajar dan kegiatan pembelajaran remedial. Kuesioner diberikan kepada 3 orang guru mata pelajaran Bahasa Indonesia dan 15 peserta didik kelas VIII.

Berikut data hasil rekaptulasi peserta didik yang memperoleh nilai di bawah KKM berdasarkan jenis teks yang dipelajari. 


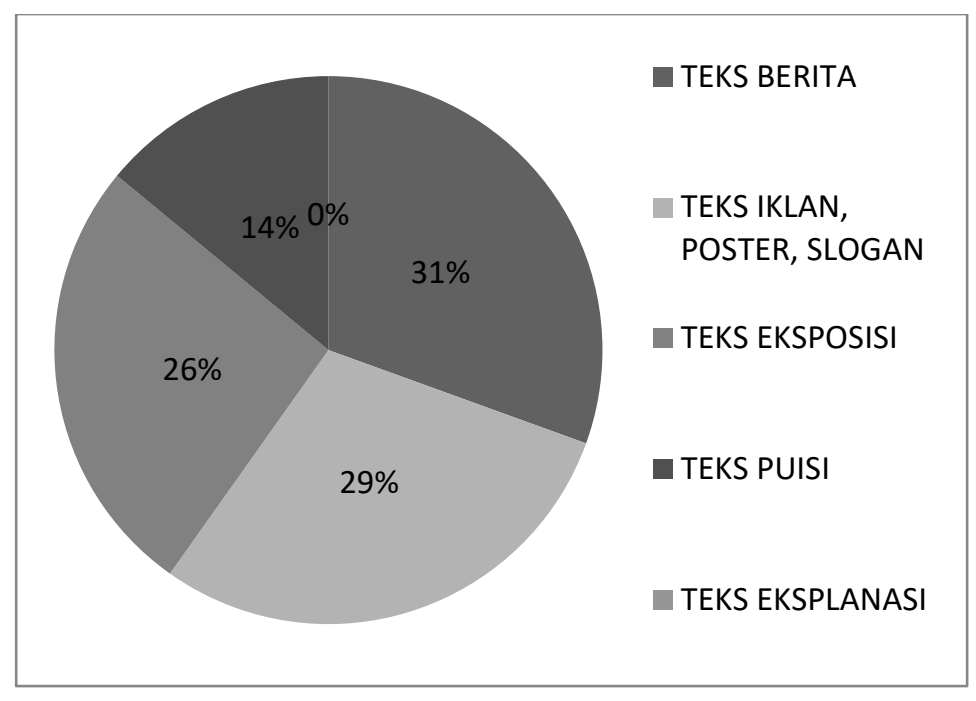

Gambar 2. Data Jumlah Peserta Didik Tidak Tuntas

Berdasarkan Jenis Teks yang Dipelajari Hasil belajar Bahasa Indonesia di setiap kelas tidak selalu $100 \%$ tuntas di setiap KD-nya. Ada saja peserta didik yang tidak tuntas hasil belajarnya. Ada peserta didik yang memperoleh nilai di bawah KKM, baik untuk KD pengetahuan atau KD keterampilan.

Di SMP Negeri 179, nilai KKM mata pelajaran Bahasa Indonesia adalah 75. Dari 5 teks yang dipelajari di semester ganjil. Di setiap teksnya memiliki 4 KD yaitu meliputi 2 KD pengetahuan dan 2 KD keterampilan. Jumlah seluruh KD di semester 1 ada 20 KD. Telah dilakukan analisis terhadap hasil penilaian harian semester ganjil tahun pelajaran 2017/2018. Dari seluruh peserta didik kelas VIII, sejumlah 322 peserta didik, terdapat sejumlah peserta didik yang memiliki nilai < 75 yang menyebar di berbagai KD. Berikut data hasil rekaptulasi peserta didik yang memperoleh nilai di bawah KKM berdasarkan jenis teks yang dipelajari.

Data ketidaktuntasan belajar terbesar ada di teks berita (98 peserta didik). Selanjutnya berturutturut teks iklan-poster-slogan (94 peserta didik), teks eksposisi (84 peserta didik), teks puisi (45 peserta didik).

Dalam modul teksberita di dalamnya ada $4 \mathrm{KD}$ yang terdiri dari $2 \mathrm{KD}$ pengetahuan dan $2 \mathrm{KD}$ keterampilan.

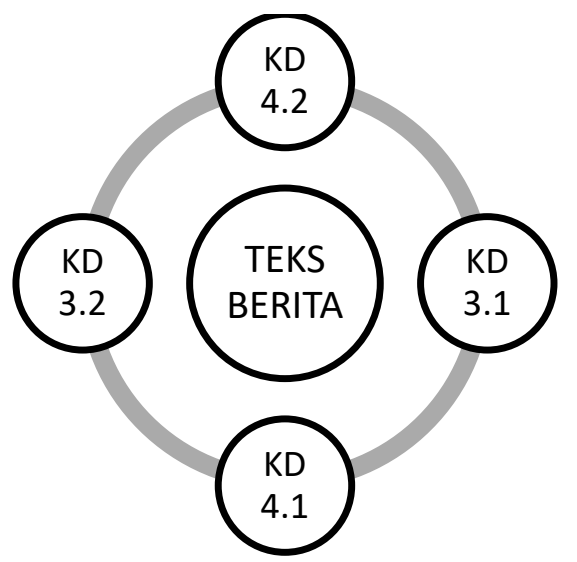

Gambar 3 Rancangan KD dalam Modul 
Tabel 1. KD dalam Teks Berita

\begin{tabular}{|l|l|}
\hline \multicolumn{1}{|c|}{ Pengetahuan } & \multicolumn{1}{|c|}{ Keterampilan } \\
\hline $\begin{array}{l}\text { 3.1 mengidentifikasi unsur-unsur teks } \\
\text { berita (membanggakan dan } \\
\text { memotivasi) yang didengar dan dibaca }\end{array}$ & $\begin{array}{l}4.1 \text { menyimpulkan isi berita (membanggakan } \\
\text { dan memotivasi) yang didengar dan dibaca }\end{array}$ \\
\hline $\begin{array}{l}\text { 3.2 menelaah struktur dan kebahasaan } \\
\text { teks berita (membanggakan dan } \\
\text { memotivasi) yang didengar dan dibaca }\end{array}$ & $\begin{array}{l}4.2 \text { menyajikan data dan informasi dalam bentu } \\
\text { berita secara lisan dan tulis dengan } \\
\text { memperhatikan struktur, kebahasaan, atau } \\
\text { aspek lisan (lafal, intonasi, mimik, dan kinestetk }\end{array}$ \\
\hline
\end{tabular}

Dalam teks berita ada $4 \mathrm{KD}$ yang terdiri dari KD pengetahuan dan keterampilan. KD pe-ngetahuan berpasangan dengan KD keterampilan. Setiap KD diturunkan menjadi indikator dengan kata kerja operasional tertentu.

Tabel 2 Indikator Pembelajaran Bahasa Indonesia Teks Berita

\begin{tabular}{|l|l|}
\hline KD & \multicolumn{1}{|c|}{ Indikator } \\
\hline 3.1 & $\begin{array}{l}\text { (1) dapat menyimpulkan ciri isi teks berita dengan } \\
\text { (2) dapat menyimpulkan ciri tujuan teks berita dengan benar. } \\
\text { (3) dapat menyimpulkan unsur-unsur teks berita dengan benar }\end{array}$ \\
\hline 4.1 & $\begin{array}{l}\text { (1) terampil menyimpulkan isi teks berita dengan benar } \\
\text { (2) terampil menuliskan kembali isi berita dengan singkat dan tepat }\end{array}$ \\
\hline 3.2 & $\begin{array}{l}\text { (1) dapat menganalisis struktur teks berita dengan tepat } \\
\text { (2) dapat menganalisis unsur kebahasaan teks berita dengan tepat }\end{array}$ \\
\hline 4.2 & $\begin{array}{l}\text { (1) terampil menyajikan data dan informasi dalam teks berita dengan struktur dan } \\
\text { (2) terampil menyajikan data dan informasi dalam teks berita lisan dengan struktur isi, } \\
\text { kebahasaan, intonasi, jeda, dan kinestetik yang tepat }\end{array}$ \\
\hline
\end{tabular}

Dari setiap indikator di atas ditentukan penilaian, jenis kegiatan pembelajaran, uraian materi, butir soalnya untuk mengukur keberhasilan pembelajarannya.

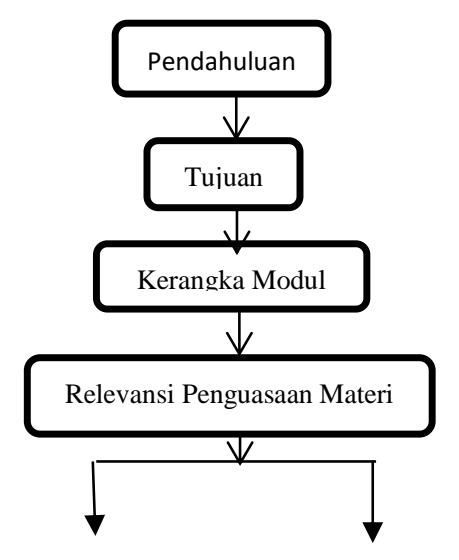




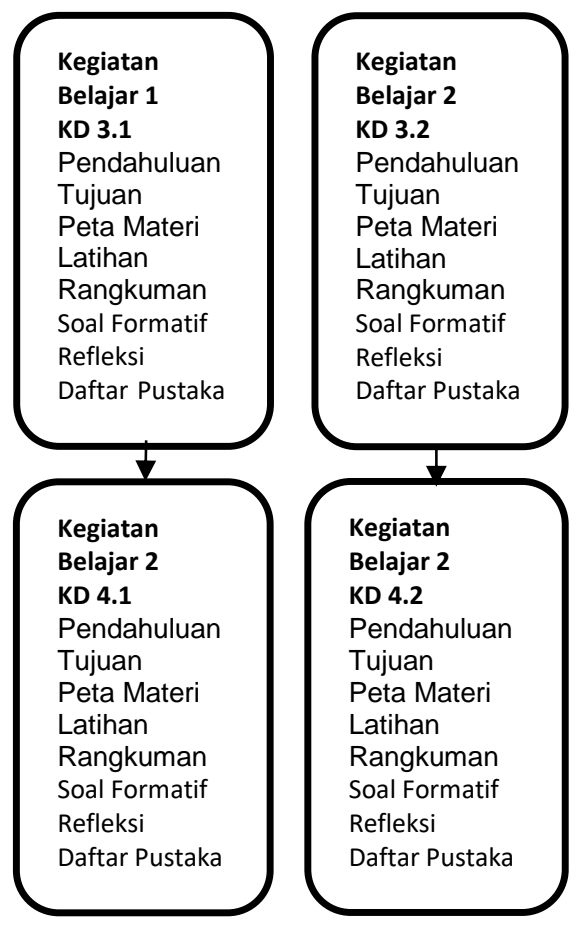

Gambar 4 Rancangan Penyajian Modul

Uji keterbacaan dilakukan dengan mengambil sampel paragraf teks dari 4 kegiatan belajar. Setiap paragraf berisi 100 kata. Setelah dilakukan penghitungan dengan rumus uji keterbacaan fog index diperoleh hasil sebagai berikut:

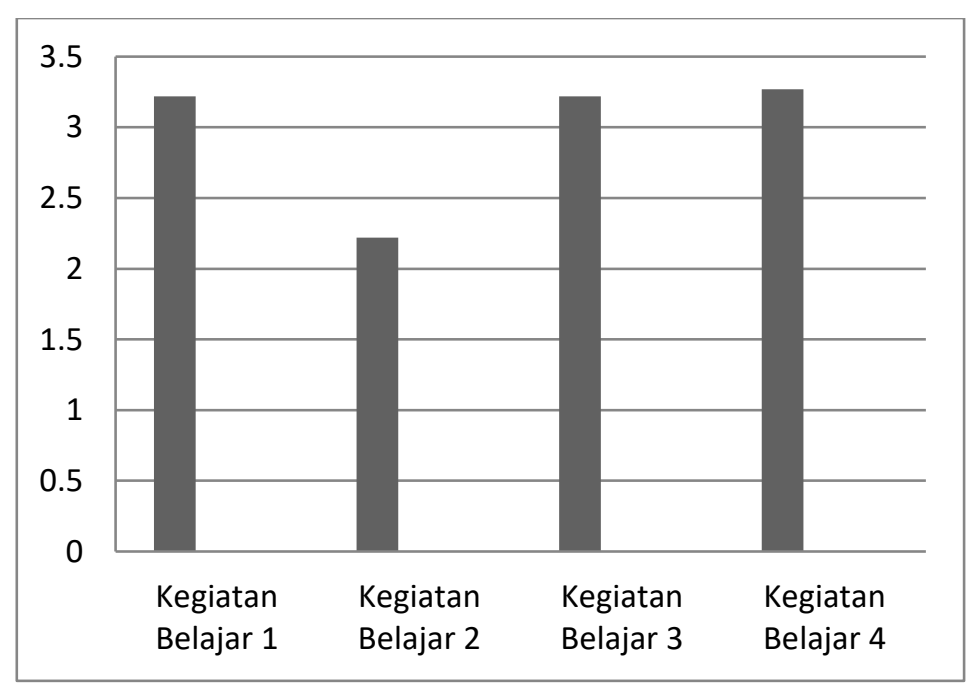

Gambar 5. Grafik Uji Keterbacaan

Berdasarkan data di atas diketahui bahwa dari 4 bagian bacaan yang diuji, diperoleh hasil sebagai berikut. Kegiatan Belajar 1, angka keterbacaannya 3,22 dalam kategori sangat mudah. Kegiatan Belajar 2, angka keterbacaannya 2,22 dalam kategori sangat mudah. Kegiatan Belajar 3, angka keterbacaannya 3,22 dalam kategori sangat mudah. Kegiatan Belajar 4, angka keterbacaannya 3,27 dalam kategori 
sangat mudah. Angka rata-rata keterbacaan yang diperoleh sebesar 3,01 masuk dalam kategori sangat mudah (Sitepu, 2015: 121-122).

\section{Hasil Uji Telaah Pakar}

Uji telaah pakar telah dilakukan untuk produk yang dihasilkan. Instrumen yang digunakan adalah kuesioner dengan skala 1-4. Acuan penilaiannya skala likert (Kunto, 1986:236). Penguji materi dan bahasa Dr. Ima Rohimah, M.Pd. Beliau adalah doktor alumni UNJ Prodi Bahasa yang merupakan widyaiswara di Badan Diklat DKI, penulis buku, dan penulis modul. Sebelumnya, beliau adalah guru Bahasa Indonesia yang ditunjuk pemerintah sebagai pengembang kurikulum 2013 untuk Mata pelajaran Bahasa Indonesia, instruktur nasional, dan penelaah buku paket.

Berdasarkan penilaian ahli materi terhadap modul pembelajaran remedial Bahasa Indonesia diperoleh hasil sebagai berikut.

Tabel 5. Rekapitulasi Uji Ahli Materi

\begin{tabular}{|l|c|}
\hline Komponen & Rata-rata Penilaian \\
\hline Kelayakan Isi & $\mathbf{3 , 8}$ \\
\hline Kesesuaian uraian materi dengan KI dan KD & 4,0 \\
\hline Keakuratan materi & 3,6 \\
\hline Mendorong kemandirian belajar & 4,0 \\
\hline Kelayakan Penyajian Isi & $\mathbf{4 , 0}$ \\
\hline Kesistematisan dan Keruntunan & 4,0 \\
\hline Pendukung penyajian & 4,0 \\
\hline Penyajian bahan pembelajaran & 4,0 \\
\hline Koherensi dan Keruntunan alur berpikir & 4,0 \\
\hline Kelayakan Bahasa & $\mathbf{3 , 8}$ \\
\hline Kelugasan Bahasa & 3,3 \\
\hline Komunikatif & 4,0 \\
\hline Kesantunan Bahasa & 4,0 \\
\hline Kesesuaian dengan tingkat perkembangan peserta & 4,0 \\
\hline Penggunaan istilah, symbol, atau ikon & 4,0 \\
\hline Rata-rata & $\mathbf{3 , 8}$ \\
\hline
\end{tabular}




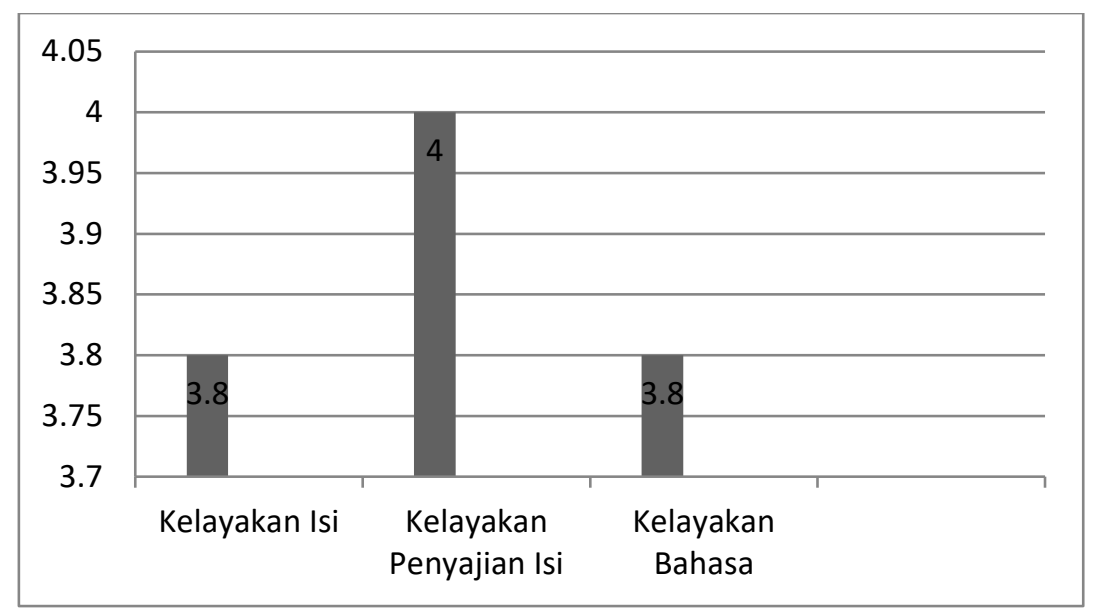

Gambar 6. Grafik Hasil Uji Ahli Materi

Berdasarkan grafik di atas, diperoleh data sebagai berikut. Kelayakan modul dari segi isi kelayakan isi adalah 3,8. Kelayakan penyajian isi adalah 4,0. Kelayakan Bahasa adalah 3,8. Rata-rata kelayakan modul dari segi materi dan bahasa sudah memiliki kualitas sangat baik.

Tabel 6. Rekapitulasi Uji Ahli Desain

\begin{tabular}{|l|c|}
\hline Komponen & Rata-rata Penilaian \\
\hline Ukuran modul & 4,0 \\
\hline Desain Sampul Modul & 3,7 \\
\hline Tata letak sampul modul & 3,3 \\
\hline Judul buku yang digunakan & 4,0 \\
\hline Ilustrasi sampul buku & 3,0 \\
\hline Konsistensi tata letak & 4,0 \\
\hline Harmonisasi unsur tata letak & 3,7 \\
\hline Kelengkapan unsur tata letak & 4,0 \\
\hline Tata letak mempercepat pemahaman & 4,0 \\
\hline Desain Isi Modul & 3,5 \\
\hline Tipografi isi buku sederhana & 3,5 \\
\hline Tipografi mudah dibaca & 3,7 \\
\hline Tipografi isi buku memudahkan membaca & 3,5 \\
\hline Rata-rata & 3,7 \\
\hline
\end{tabular}




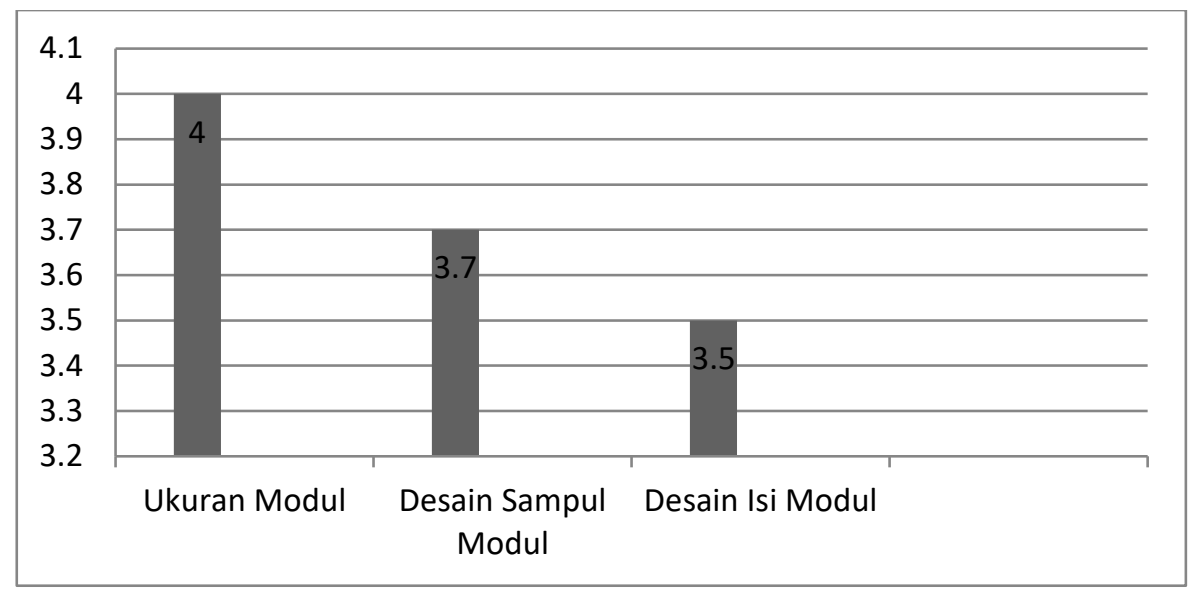

Gambar 7. Grafik Hasil Uji Ahli Desain

Penguji desain untuk produk yang dikembangkan adalah Prof. Dr. Suyitno Muslim, M.Pd. Beliau adalah pengajar Prodi Teknologi Pendidikan di Pascasarjana UNJ. Berdasarkan uji desain diperoleh data sebagai berikut.

Tabel 7. Rekapitulasi Uji Ahli Desain

\begin{tabular}{|l|c|}
\hline \multicolumn{1}{|c|}{ Komponen } & Rata-rata Penilaian \\
\hline Ukuran modul & 4,0 \\
\hline Desain Sampul Modul & 3,7 \\
\hline Tata letak sampul modul & 3,3 \\
\hline Judul buku yang digunakan & 4,0 \\
\hline Ilustrasi sampul buku & 3,0 \\
\hline Konsistensi tata letak & 4,0 \\
\hline Harmonisasi unsur tata letak & 3,7 \\
\hline Kelengkapan unsur tata letak & 4,0 \\
\hline Tata letak mempercepat pemahaman & 4,0 \\
\hline Desain Isi Modul & 3,5 \\
\hline Tipografi isi buku sederhana & 3,5 \\
\hline Tipografi mudah dibaca & 3,7 \\
\hline Tipografi isi buku memudahkan membaca & 3,5 \\
\hline Rata-rata & 3,7 \\
\end{tabular}




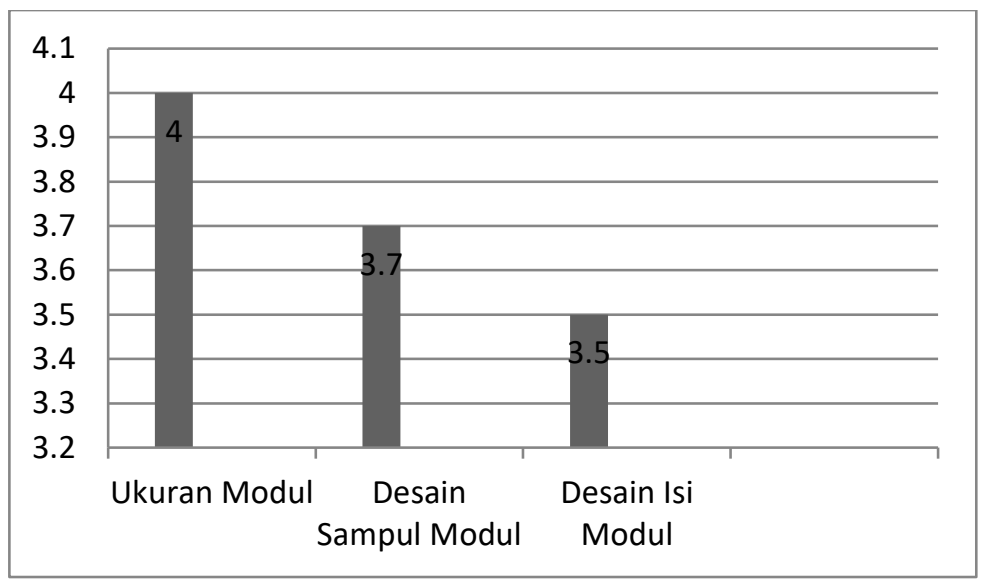

Gambar 8. Grafik Hasil Uji Ahli Desain

Menurut data di atas, modul remedial sudah memiliki kualitas desain yang sangat baik dari segi desain. Hal tersebut dibuktikan oleh hasil penilaian dengan perolehan setiap aspek sebagai berikut. Ukuran modul bernilai 4 kategori sangat baik. Desain sampul modul bernilai 3,7 dengan kategori sangat baik. Desain isi modul juga bernilai 3,5 yang masih dalam kategori baik.

Tabel 8. Rekapitulasi Uji Satu-Satu

\begin{tabular}{|l|l|l|l|c|}
\hline \multirow{2}{*}{ Komponen } & \multicolumn{3}{|l|}{ Responden } & \multirow{2}{*}{ Rata-rata Penilaian } \\
\cline { 2 - 5 } & $\mathbf{1}$ & $\mathbf{2}$ & $\mathbf{3}$ & \\
\hline Kualitas pembelajaran & 3,6 & 3,8 & 4,0 & 3,8 \\
\hline Fungsi dan ukuran modul & 4,0 & 3,6 & 3,3 & 3,6 \\
\hline Bahasa dan struktur kalimat & 3,8 & 3,8 & 4,0 & 3,9 \\
\hline Tata letak & 2,6 & 3,4 & 3,4 & 3,1 \\
\hline Tipografi & 4,0 & 4,0 & 3,4 & 3,8 \\
\hline Ilustrasi & 4,0 & 4,0 & 4,0 & 4,0 \\
\hline Warna & 3,4 & 4,0 & 4,0 & 3,8 \\
\hline \multirow{2}{*}{ Rata-rata } & & & & 3,7 \\
& 3,6 & 3,8 & 3,7 & (sangat baik) \\
\hline
\end{tabular}




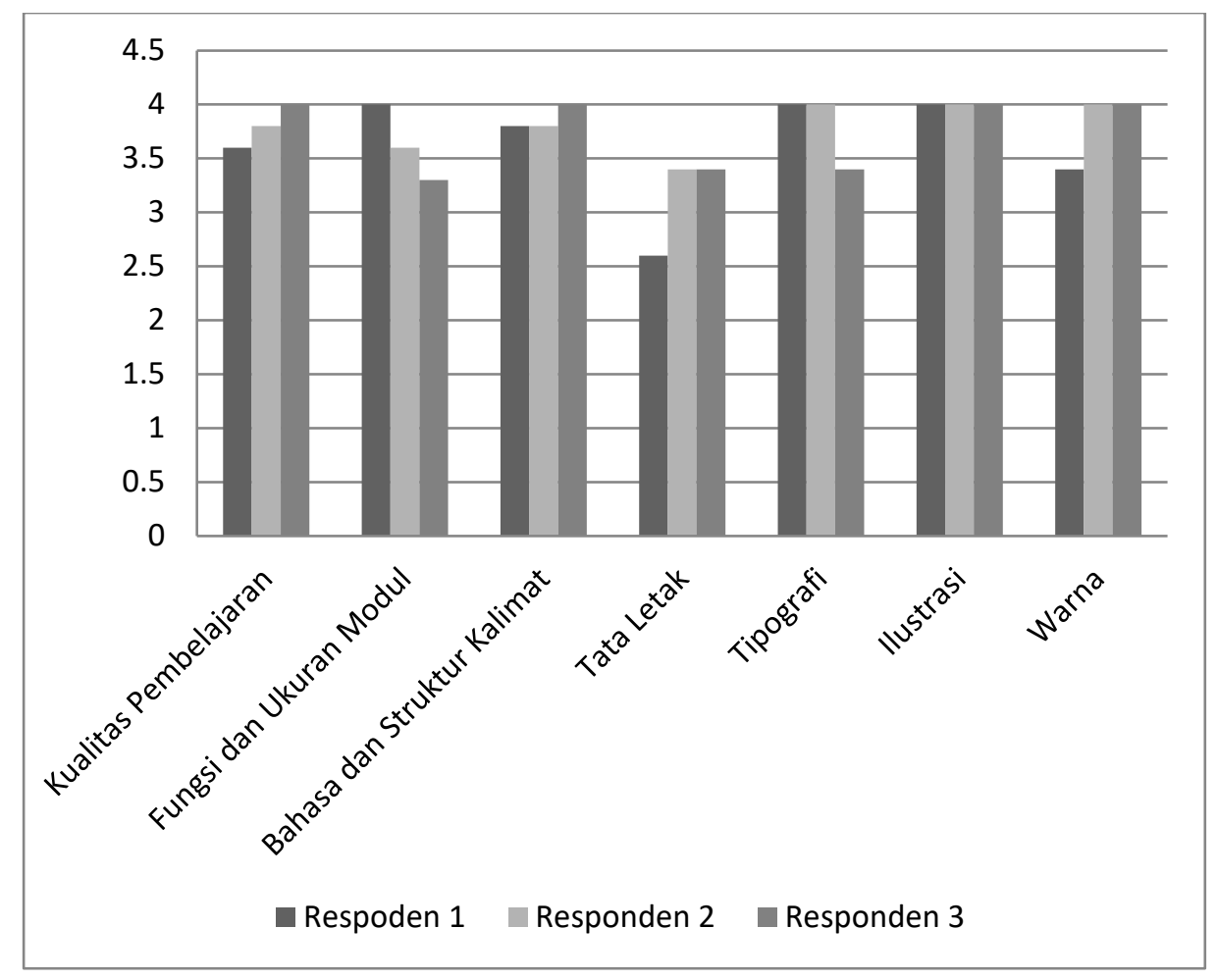

Gambar 9. Hasil Uji Satu-Satu

Dari di atas menunjukkan bahwa hasil rata-rata kualitas modul baik dengan angka rata-rata sebesar 3,7 dengan kategori sangat baik. Hal ini menunjukkan kalau modul layak untuk digunakan.

\section{Hasil Uji Kelompok Terbatas}

Uji kelompok terbatas dilaksanakan di SMP Negeri 179 kepada 5 orang peserta didik yang perolehan nilainya tidak tuntas di KD 3.1 dan 4.1 di semester 1. Mereka diminta belajar mandiri menggunakan modul dengan menggunakan kegiatan belajar yang sesuai dengan KD yang tidak tuntas. Untuk peserta didik yang tidak tuntas di KD 3.1, mereka belajar dengan modul kegiatan belajar 1. Untuk peserta didik yang tidak tuntas di KD 4.1, mereka belajar menggunakan modul kegiatan belajar 2 .

Mereka sengaja diminta belajar di luar kelas. Dua orang peserta didik mengerjakan di taman sekolah sedangkan 3 peserta didik lainnya di perpustakaan. Peneliti tidak memberikan batas waktu mempelajari modul. Peneliti memberikan kertas kosong untuk mengerjakan latihannya. Setelah selesai mempelajari modul, peneliti memberikan lembar jawaban untuk mengerjakan soal formatif. Masing-masing responden mampu mempelajari dan sekaligus mengerjakan soal tidak sampai 2 jam.

Perolehan nilainya sebagai berikut:

Tabel 9. Uji Coba Kelompok Kecil

\begin{tabular}{|l|l|c|c|c|}
\hline \multirow{2}{*}{ No. } & Nomor & \multicolumn{2}{|c|}{ Perolehan Nilai } & \multirow{2}{*}{ Keterangan } \\
\cline { 3 - 4 } & Responden & Pretest & Posttest & \\
\hline 1. & Responden 1 & 60 & 90 & Tuntas \\
\hline 2. & Responden 2 & 70 & 80 & Tuntas \\
\hline
\end{tabular}




\begin{tabular}{|l|l|l|l|l|}
\hline 3. & Responden 3 & 65 & 85 & Tuntas \\
\hline 4. & Responden 4 & 40 & 75 & Tuntas \\
\hline 5. & Responden 5 & 50 & 80 & Tuntas \\
\hline \multicolumn{2}{|c|}{ Nilai rata-rata } & 57 & 82 & $100 \%$ \\
\hline
\end{tabular}

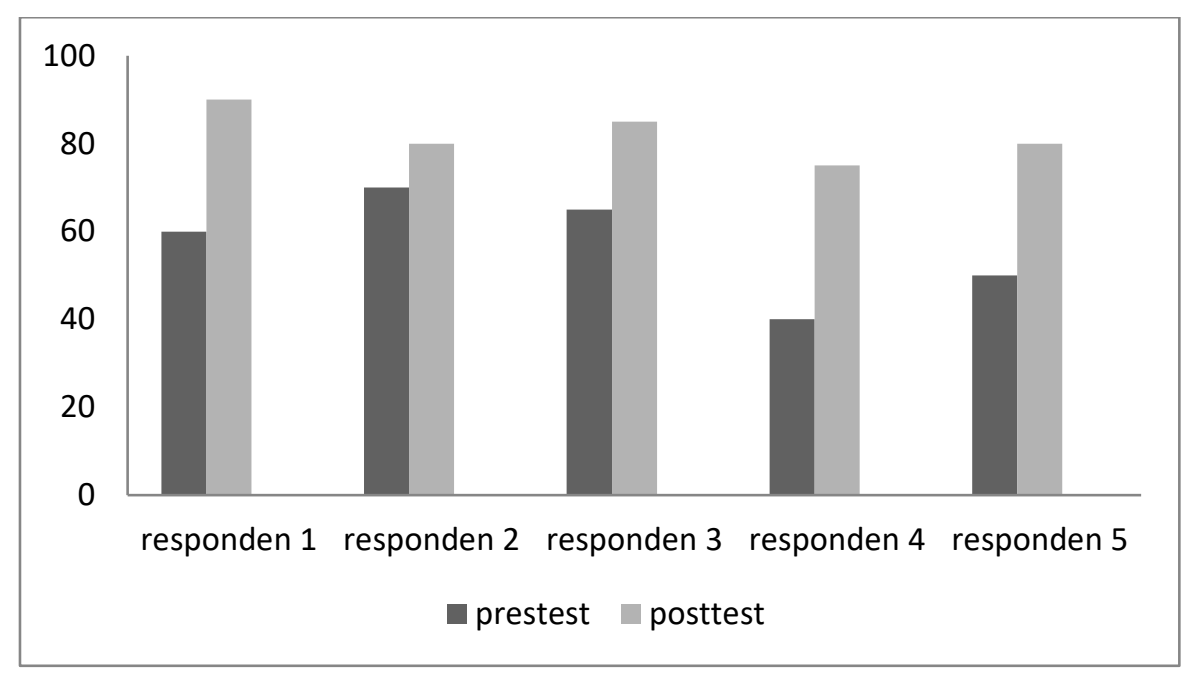

Gambar 10. Grafik Uji Coba Kelompok Kecil

Berdasarkan data di atas, maka diperoleh kesimpulan bahwa produk mampu meningkat-kan hasil belajar karena mampu menunjukkan angka perbedaan yang cukup signifikan. Rata-rata pretest 57 dan rata-rata posttest 82 .

\section{Hasil Uji Lapangan}

Uji kelompok dilaksanakan dengan 20 responden pada hari Sabtu tanggal 11 Agustus 2018. Uji coba dilakukan untuk kegiatan belajar 4 untuk KD 3.2. Hasilnya diperoleh data sebagai berikut.

Uji kelayakan produk dilakukan kepada 20 orang peserta didik dan orang guru kelas VIII mata pelajaran Bahasa Indonesia. Instrumen yang digunakan adalah kuesioner untuk mengukur kualitas produk. Kuesioner me-nyangkut aspek kualitas pembelajaran, fungsi dan ukuran modul, Bahasa dan struktur kalimat, tata letak, tipografi, ilustrasi, dan warna.

Dari hasil wawancara, diperoleh data kalau produk medial Bahasa Indonesia kualitasnya sudah sangat baik. Hal ini ditunjukkan dari hasil rekapitulasi sebagai berikut. 


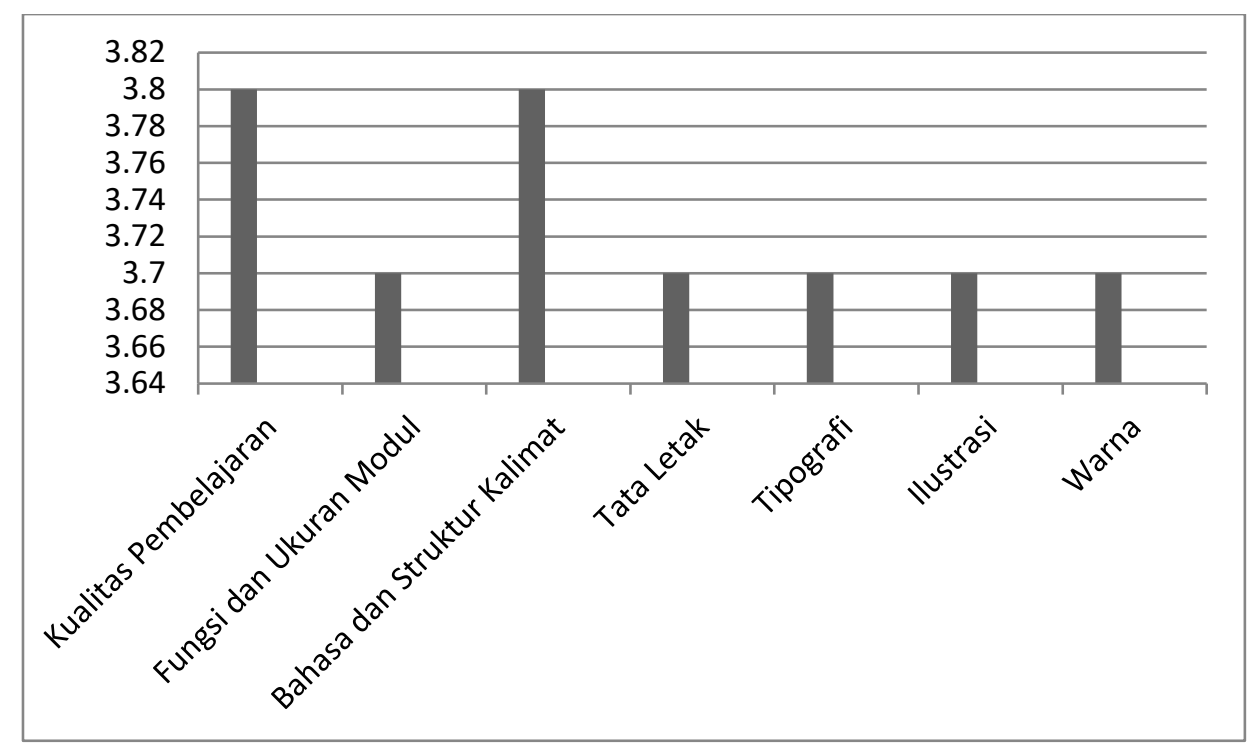

Gambar 11. Data Kualitas Produk Uji Lapangan

Berdasarkan data di atas, maka dapat disimpulkan bahwa kualitas produk rata-rata memperoleh nilai 3,7. Itu berarti, kualitas modul berada dalam kategori sangat bagus sehingga layak untuk digunakan.

Dari hasil wawancara akhir kepada guru Bahasa Indonesia kelas VIII, diperoleh informasi kalau modul sudah sesuai dengan materi yang diremedialkan sesuai dengan tuntutan KD, penyajian pembelajarannyanya juga mudah dipahami, modul memiliki kualitas yang bagus, dan dapat membantu pelaksanaan pembelajaran remedial menjadi efektif dan efisien. Harapannya ke depan, aka nada pengembangan modul remedial untuk teks yang lain.

\section{Efektivitas Produk}

Uji efektivitas dilakukan kepada 20 orang responden yang merupakan peserta didik kelas VIII SMPN 179 untuk mengerjakan soal pretest dari kegiatan belajar 3 dengan KD 3.2. Berdasarkan hasil pretest dan posttest Hasilnya menunjukkan kalau peserta didik mampu mencapai angka ketuntasan. Berdasarkan data, maka diperoleh kesimpulan bahwa produk mampu meningkatkan hasil belajar karena mampu menunjukkan angka perbedaan yang cukup signifikan antara pretest dan posttest. Rata-rata pretest 65 dan rata-rata posttest 81 . Terjadi peningkatan hasil rata-rata. Untuk mengukur tingkat perbedaan dilakukan penghitungan Uji-T dengan program SPSS. Hasilnya menunjukkan bahwa perbedaan menunjukkan angka yang cukup signifikan. 


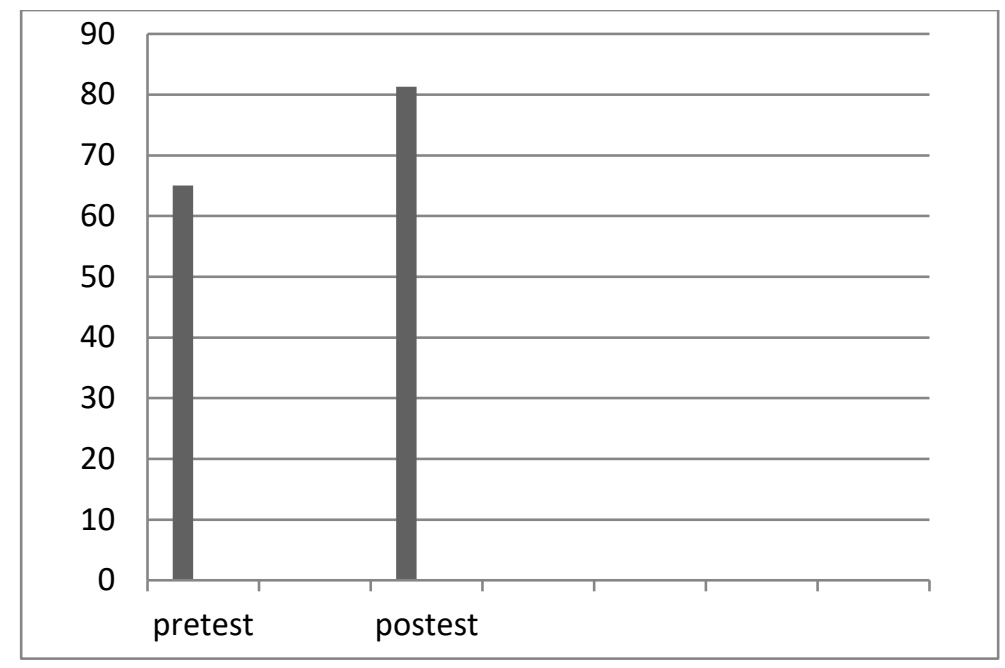

Gambar 12. Grafik Uji Coba Kelompok Luas

\section{Produk Final}

Setelah dilakukan berbagai uji coba, maka dihasilkan produk final Modul Pembelajaran Remedial Mata pelajaran Bahasa Indonesia Kelas VIII dengan deskripsi sebagai berikut.

Nama produk adalah "Modul Pem-belajaran Remedial Bahasa Indonesia Kelas VIII". Isi modul khusus untuk KD yang ada dalam teks berita.

Dalam modul ini ada 4 kegiatan belajar sesuai dengan KD yang ada di dalam teks berita. Dalam setiap kegiatan pembelajaran diuraikan tentang pendahuluan, tujuan, peta konsep, uraian materi, latihan, soal formatif, refleksi, dan daftar pustaka

Karakteristik fisik modul sebagai berikut:

Sampul: hardcover dengan jenis kertas photo paper ukuran 120 gram, ukuran letter, dasar warna putih dengan variasi gambar gradasi warna hijau, di tengah cover ada 3 lingkaran: lingkaran paling besar bergambar peta Indonesia berwarna hijau, lingkaran kecil di kanan atas bergambar laptop dan surat kabar, dan lingkaran kanan bawah bergambar tumpukan surat kabar yang terbuka halamnya.

Isi: kertas HVS ukuran letter dengan berat 80 gram. Tulisan hitam dengan jenis huruf arial 11 untuk uraian, arial 12 untuk judul, serta Bodoni MT Black untuk tulisan motivasi dengan varian ukuran yang berbeda-beda. Di dalam isi ada gambar-gambar penunjang berupa foto dan diagram yang fullcolour. Jumlah halaman mencapai xi dan 107 halaman.

Modul pembelajaran remedial Bahasa Indonesia ini dapat secara efektif meningkatkan kemampuan peserta didik terhadap sebuah KD belum dikuasai sebelumnya hingga akhirnya mampu mencapai tingkat kompeten (KKM). Dengan demikian keberhasilan pembelajaran remedial dapat tercapai. Remedial merupakan program pembelajaran yang diperuntukkan bagi peserta didik yang belum mencapai KKM dalam satu KD tertentu (Gantini, 2017:51). Proses pemahaman kesulitan belajar dapat dilakukan sendiri oleh peserta didik. Kemudian, peserta didik memperbaiki cara belajar dan 
memanfaatkan modul sebagai sarana utama mengatasi kesulitan sesuai dengan KD yang tidak terkuasai dengan tuntas.

Dengan demikian, peserta didik dapat menyembuhkan kesulitan belajarnya. Arifin menjelaskan tujuan pembelajaran remedial adalah untuk membantu dan menyembuhkan peserta didik yang mengalami kesulitan belajar melalui perlakuan pengajaran (Arifin, 2017, 304). Perlakuan pembelajaran dilakukan oleh peserta didik dengan pemanfaatan modul yang dapat dilakukannya di luar jam belajar. Ia dapat mempelajari sepuas hatinya sampai ia betul-betul menguasai pembelajaran.

Sikap belajar mandiri tercermin dalam pemanfaatan modul remedial. Belajar mandiri memang sebuah kegiatan belajar aktif didorong oleh motif untuk menguasai suatu kompetensi guna mengatasi masalahnya sendiri (Mudjiman, 2011:1) Ketika peserta didik memakai modul remedial untuk mengatasi sendiri kesulitannya dengan memahami betul masalah belajarnya, lalu dia mengikuti semua langkah remedial di dalam modul, sampai dengan mengukur kemampuan hasil belajarnya, maka di sinilah sudah terjadi sikap belajar mandiri pada diri peserta didik.

Pengembangan produk yang dihasilkan mampu mengatasi masalah yang berkait dengan kegiatan kegiatan remedial. Produk ini telah dikembangkan sebagai sebuah sistem, modul cetak pembelajaran Bahasa Indonesia yang dikembangkan meng-gunakan sebuah desain pengembangan. Ber-dasarkan hasil penelitian, produk pengembangan sudah dikembangkan sebagai sebuah studi sistematis tentang desain dan evalusi program, proses, dan produk yang harus memenuhi kriteria konsistensi internal dan efektivitas (Prawiradilaga, 1994:137).

Dilihat dari sudut Teknologi Pendidikan, produk ini mampu membuat pembelajaran remedial berlangsung secara efektif dan efisien.

\section{KESIMPULAN}

Guru dan peserta didik membutuhkan sarana pembelajaran berupa modul remedial untuk mempermudah pelaksanaan kegiatan remedial. Modul cetak yang dikembangkan diharapkan dapat dipelajari secara mudah dan berulang-ulang. Modul yang diinginkan modul yang memberikan kesempatan peserta didik untuk melaksanakan kegiatan remdial secara mandiri.

Pengembangkan modul cetak pem-belajaran remedial untuk mata pelajaran Bahasa Indonesia Kelas VIII telah berhasil dilaksanakan. Modul remedial yang dikembangkan untuk pembelajaran yang berkait dengan teks berita untuk KD 3.1; KD 4.1; KD 3.2; dan KD 4.2. Modul dikembangkan dengan Model Rowntree dengan prosedur 3 langkah utama, yaitu tahap perencanaan, persiapan penulisan, penulisan dan penyuntingan.

Modul Pembelajaran Remedial Bahasa Indonesia SMP kelas VIII sudah layak untuk digunakan. Hasil uji keterbacaan modul menunjukkan bahwa isi modul kategori keterbacaannya sangat mudah sehingga isinya akan mudah dipahami oleh peserta didik dalam kegiatan remedial.

Hasil uji pakar media dengan perolehan rata-rata skala likert sebesar 3,7 dengan predikat sangat baik. Komponen ukuran modul, desain sampul, dan isi sudah memenuhi persyaratan. 
Hasil uji pakar materi dengan nilai skala likert sebesar 3,8 dengan predikat sangat baik. Modul sudah sesuai dengan KI dan KD yang ingin dikembangkan, materi akurat, mendorong kemandirian belajar, sistematis, runtun, penyajian bagus. Bahasa yang digunakan lugas, komunikatif, dan sesuai dengan perkembangan peserta didik.

Hasil uji coba kualitas oleh peserta didik. Angka rata-rata skala likert sebesar 3,73 dengan predikat sangat baik. Modul sudah bagus kualitas pembelajarannya, fungsi dan ukuran, bahasa dan struktur kalimat, tata letak, tipografi, ilustrasi, serta warnanya sudah sangat bagus.

Modul cetak pembelajaran remedial mata pelajaran Bahasa Indonesia sangat efektif untuk mencapai ketuntasan belajar Bahasa Indonesia peserta didik kelas VIII. Hasil uji normalitas dapat disimpulkan bahwa pada data nilai pretest memiliki nilai signifikan dan data nilai pretest berdistribusi normal. Data nilai posttest juga menunjukkan bahwa nilai signifikan dan data nilai posttest berdistribusi normal. Ada perbedaan rata-rata nilai yang cukup signifikan antara nilai pretest dan posttest sehingga modul mampu efektif untuk digunakan untuk meningkatkan hasil pembelajaran mencapai angka di atas KKM.

Penelitian pengembangan modul cetak pembelajaran remedial mata pelajaran bahasa Indonesia memberikan implikasi sebagai berikut. Hasil penelitian dapat memenuhi kebutuhan para peserta didik untuk semakin mudah dalam pembelajaran remedial secara mandiri sehingga semakin mencapai tingkat kompetensi yang ditentukan.

Hasil penelitian dapat mengembangkan media yang dapat membantu peserta didik mendapatkan sarana belajar berupa modul sehingga dapat melakukan sendiri kegiatan remedialnya di luar jam belajar sekolah dengan sangat mudah.

Hasil penelitian dapat mempermudah guru-guru pembelajaran bahasa Indonesia dalam menjalankan kewajibannya untuk membantu peserta didik melaksanakan kegiatan pembelajaran secara praktis dan mudah.

Berdasarkan hasil penelitian, berikut rekomendasi yang dapat diberikan. Modul cetak pembelajaran remedial ini dapat digunakan oleh guru kelas VIII mata pelajaran bahasa Indonesia untuk mempermudah pelaksanaan kegiatan remedial.

Penelitian pengembangan modul remedial dapat dijadikan contoh pengembangan modul teks lain di dalam mata pelajaran bahasa Indonesia di tingkat kelas manapun karena cukup efektif digunakan dalam kegiatan remedial.

Hasil penelitian dapat dijadikan bahan masukan kepada para guru untuk mampu mendesain dan mengembangkan sarana pembelajaran yang efektif dan efisien di dalam pembelajaran mata pelajaran selain bahasa Indonesia.

Hasil penelitian dapat menjadi bahan referensi untuk kemajuan ilmu. Penelitian lanjutan dapat dilakukan untuk penerapan atau penyebaran hasil pengembangan produk di bidang yang sama ataupun pengembangan media pembelajaran di bidang lainnya. 


\section{DAFTAR PUSTAKA}

Arifin, Zaenal. Evaluasi Pembelajaran: Prinsip, Teknik, dan Prosedur. Bandung: PT Remadja Rosda Karya, 2017.

Chou, Chin-Cheng. "An Analysis of The 3D and Interaktif ResponseApproach Effects on The Science Remedial Teaching for Fourth Grade Underachieving Students, " dalam EURASIA Journal of Mathematcs Science and Technology Education.http://www.iserjounals.com/journals/eurasia.2017.00658a (diakses 16 Maret 2018)

Gantini, Pipit dan Dodo Suhendar. Penilaian Hasil Belajar. Jakarta: Esensi, 2017

Haryati, Mimin. Model \& Teknik Penilaian pada Tingkat Satuan Pendidikan. Jakarta: Gaung Persada Press, 2010.

Ibrahim, Nurdin. Perspektif Pendidikan Terbuka Jarak Jauh: Kajian Teoritis dan Aplikasi. Jakarta: Bumi Aksara, 2010.

Jangid, Neelu dan Umed Singh Inda, "Effectivenes of Remedial Teaching on Thinking Strategies of Slow Learners," The International Journal of India Psychology. Vol. 4 Issue 1, No. 84 http://www.ijip.in/index.php/component/content/article. (diakses 16 Maret 2018).

Kamar, Nurul, Sentot Kusari, dan Siti Zubaidah, "Pengembangan Asesmen Formaif dan Remediasi Berbasis Komputer pada Pokok Bahasan Suhu dan Kalor SMP Kelas VII," dalam Jurnal Ilmiah Pendidikan Fisika "Lensa” Vol. 4 No. ISSN 2338-4417.

Kementerian Pendidikan dan Kebudayaan. Panduan Penilaian oleh Pendidik dan Satuan Pendidikan untuk SMP. Jakarta: Kemendikbud, 2016.

Mudjiman, Haris. Belajar Mandiri. Surakarta: LPP UNS dan UNS Press, 2011. Muldiyana, Ibrahim, Muslim. "Penengembangan Modul Cetak pada Mata Pelajaran Produktif Teknik Komputer dan Jaringan di SMP Negeri 2 Watampone" dalam Jurnal Teknologi Pendidikan Vol 20 No.1 2018.

Nilasari, Efi, Ey Tri Djatmika, dan Anang Santoso, "Pengaruh Penggunaan Modul Pembelajaran Kontekstual terhadap Hasil Belajar Siswa Kelas V Sekolah Dasar” dalam Teori, Penelitian, dan Pengembangan. Vol.1 No. 72016.

Ningsih, Pudji Hariati. "Pengaruh Penggunaan Modul dan Penggunaan Buku Paket terhadap Prestasi Belajar Mata Pelajaran IPS Siswa Kelas V SDN Sukabumi 10,”Jurnal Penelitian dan Pendididikan IPS (JPPI) http://ejournal.unikama.ac.id. (diakses 20 Maret 2018)

Prastowo, Andi. Panduan Kreatif Memuat Bahan Ajar Inovatif. Yogyakarta: Diva Press, 2011.

Prasetyo, Rida Ikrar, Eko Suprapto, dan Ari Dwi Utami. "Penerapan Model Pembelajaran Remedial Berbasis Web pada Materi Rumus dan Fungsi," Dinamika: Jurnal Praktik Penelitian Tindakan Kelas Pendidikan Dasar dan Menengah vol. 6 No.2 April 2016

Prawiradilaga, Dewi S (penerjemah), Teknologi Pembelajaran: Definisi dan Kawasannya. Jakarta: Unit Penerbit UNJ, 1994.

Rowntree, Derek. Preparing Materials for Open, and Flexible Learning. London: Kogan Page, 1994. 
Seputra, Deni Cridiana dan Sri Wening, "Hubungan Pemanfaatan Modul Pembelajaran dengan Hasil Belajar Pembuatan Pola Kemeja Pria Kelas XI di SMK Negeri 3 Purworejo," Jurnal Pendidikan Teknik Busana UNY, Edisi April 2017.

Sitepu, B.P. Penyusunan Buku Pelajaran. Jakarta: Verum Publishing, 2006.

Sugiman. Guru Pembelajar: Modul Matematika SMP. Jakarta: Direktorat Jenderal Guru dan Tenaga Kependidikan Kementerian Pendidikan dan kebudayaan, 2016.

Sugiono. Metode Penelitian Kuantitatif, Kualitatif, dan R\&D. Bandung: Alfabeta, 2010.

Suparman, Atwi. Desain Instruksional Modern. Jakarta: Erlangga, 2012.

Winarko, Adhin Setyo, Widja Sunarno, dan Mohammad Masykuri, "Pengembangan Modul Elektronik Berbasis POEI (Prediksi, Observasi, Eksperimen, Interpretasi) pada Materi Sistem Indera Kelas XI SMA Negeri 3 Ponorogo,” Bioedukasi Vol. 6 No. 2 Agustus 2013.

Zein, Mas'ud. Mastery Learning: Faktor-Fakor yang Mempengaruhinya. Yogyakata: Asmaja Pressindo, 2014. 